\title{
Development of Cholinergic Retinal Neurons from Embryonic Chicken in Monolayer Cultures: Stimulation by Glial Cell-Derived Factors
}

\author{
Hans-Dieter Hofmann \\ Max-Planck-Institut für Hirnforschung, D-6000 Frankfurt/M. 71, FRG
}

In recent years evidence has indicated that, like the PNS, the development of the CNS is influenced by neuronotrophic polypeptide factors. In the present study, cultures of dissociated retinal neurons from 8-d-old chicken embryos were used to investigate the role of neuronotrophic factors (NTF) in the development of the neural retina.

CAT, which in vivo is located in amacrine cells of the retina, served as a marker for studying the in vitro development of cholinergic retinal neurons. Differentiation of cholinergic cells under control conditions was indicated by a 10 -fold increase of enzyme activity during a 7-d culture period. Addition of media conditioned by high-density retinal cultures resulted in a further stimulation of CAT activity by $100-400 \%$. The CAT-stimulating activity was associated with a high-molecular-weight component of the retina conditioned medium (RCM) and was sensitive to protease treatment, but was not affected by other hydrolytic enzymes. The putative cholinergic factor was secreted by retinal cultures virtually free of neurons, suggesting that it is mainly produced by Müller cells. CAT-stimulating activity was also present in extracts from embryonic chicken retinae and medium conditioned by rat retinal cultures. NGF, anti-NGF antiserum, extracts from chicken brain tissues, and a number of other extracts and conditioned media, all known to contain neuronotrophic activities, were found to have no influence on cholinergic development in chicken retinal cultures. An extract from nonretinal eye tissue containing ciliary neuronotrophic factor (CNTF) stimulated CAT activity to the same extent as did RCM.

These results suggest that the development of cholinergic retinal neurons depends on a possibly CNTF-like polypeptide factor that is supplied by their glial environment.

It is well documented for the PNS that neuronal development and maintenance of function is regulated by neuronotrophic factors (NTF) that are delivered by target tissues or by the glial environment. These polypeptide factors exert a general stimulating influence on survival and differentiation of selected neurons and possibly interact with other macromolecular factors that more specifically influence developmental processes like transmitter choice and neurite growth (Patterson, 1978; Varon

\footnotetext{
Received Apr. 22, 1987; revised Aug. 4, 1987; accepted Sept. 5, 1987.

I wish to thank Susanne Wallenstein and Gerlinde Heiss-Herzberger for excellent technical existence and Irmgard Odenthal for typing the manuscript.

Correspondence should be addressed to Dr. Hofmann, Max-Planck-Institut für Hiirnforschung, Deutschordenstr. 46, D-6000 Frankfurt/M. 71, FRG.

Copyright (C 1988 Society for Neuroscience $0270-6474 / 88 / 041361-09 \$ 02.00 / 0$
}

and Adler, 1981; Varon and Manthorpe, 1984). The concept is based mainly on results obtained with NGF, the prototype neuronotrophic factor (Levi-Montalcini and Angeletti, 1968; Thoenen and Barde, 1980). Neuronotrophic activities different from NGF both in their molecular properties and in their target-cell specificity have been found in many tissue extracts or media conditioned by cultured cells (Barde et al., 1983; Berg, 1984).

Although there is increasing evidence that similar or even identical polypeptide factors are involved in the regulation of neuronal survival and functional differentiation in the brain, knowledge of trophic interactions in the CNS is still very fragmentary. Recently, however, the use of a number of different experimental approaches has provided convincing evidence that NGF plays an important role in the differentiation of cholinergic neurons in nuclei of the basal forebrain, and that the trophic molecule is produced in the target regions to which these neurons project (Honegger and Lenoir, 1982; Hefti et al., 1985, 1986; Hefti, 1986; Large et al., 1986). This example demonstrates that selection of an appropriate assay system is crucial for the detection of trophic interactions in the brain. In this respect the neural retina seems a suitable model system. Its cellular components and its structural organization have been studied extensively (for a review, see Ramon y Cajal, 1895; Kaneko, 1979; Sterling, 1983; Iuvone, 1986). In addition, the retina is connected with other brain regions only via the the optic nerve and thus potential sources and targets of neuronotrophic activities are more easily identified as compared to those of other parts of the CNS.

As expected from the concept that target-derived factors are involved in the regulation of neuronal cell death, it has been shown that in vitro survival of retinal ganglion cells from embryonic chicken or newborn rats is enhanced when coculturcd with the corresponding target tissue (Nurcombe and Bennett, 1981; McCaffery et al., 1982). Interestingly, a NTF that was detected and purified from pig brain on the basis of its survival supporting activity on peripheral sensory neurons (Barde et al., 1982) also addresses cultured rat retinal ganglion cells (Turner, 1985; Johnson et al., 1986).

This study provides evidence that the development of retinal neurons depends on polypeptide factors that, in accordance with the concept described above, are produced by glial cells within the retina. CAT activity was used as a marker for the development of cholinergic cells in monolayer cultures prepared from embryonic chicken retinae. In chicken (Baughman and Bader, 1977; Millar et al., 1985), as in other species (Neal, 1983; Masland et al., 1984; Schmidt et al., 1985; Voigt, 1986), ACh synthesis has been localized in a subpopulation of amacrine and 


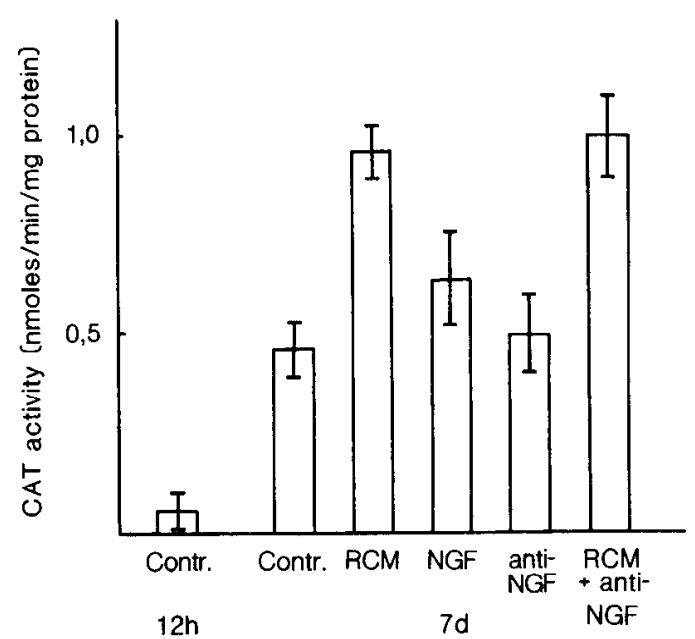

Figure 1. CAT in monolayer cultures from E8 chicken retinae. Cells $\left(4 \times 10^{5}\right)$ were seeded per well and grown in the absence or presence of RCM (110 $\mu \mathrm{l} / \mathrm{ml}$; DMEM $/ 10 \%$ FCS; see Table 2), NGF (100 ng/ml), or anti-NGF antiserum $(5 \mu \mathrm{m} / \mathrm{ml})$ as indicated. CAT activity was determined after $12 \mathrm{hr}$ or $7 \mathrm{~d}$ in culture. Each value represents the mean of 4 measurements \pm SEM.

displaced amacrine cells. Expression of CAT activity in chicken retinal cultures is shown here to be stimulated by a protein component that seems to be specifically produced by retinal cells both in vitro and in vivo.

\section{Materials and Methods}

Materials. Tetanus toxin and rabbil antiserum to tetanus toxin were kindly supplied by Dr. Hungerer, Behringwerke, Marburg (FRG). Purification of mouse NGF and preparation of anti-NGF antiserum has been described elsewhere (Hofmann and Unsicker, 1982). Media and salt solutions for cell culture and fetal calf serum were obtained from Biochrom (Berlin). $1{ }^{1-14} \mathrm{C}$-acetyl-coenzyme $A$ was purchased from Amersham Buchler, Braunschweig (FRG) and all other chemicals and reagents were from Serva (Heidelberg) or from Sigma.

Chicken retinal cultures. Fertilized eggs obtained from a local hatchery were incubated in a humidified egg chamber at $37.8^{\circ} \mathrm{C}$. Eight-d-old (E8) embryos (stage 34 or 35 of Hamburger and Hamilton, 1951) were used for culture preparation. Neural retinae were carefully dissected free of pigment epithelium and divided into 2 halves. Each half was incu-

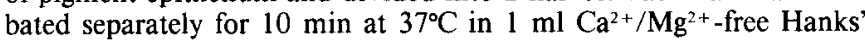
balanced salt solution (HBSS/CMF) and then for $20 \mathrm{~min}$ in $1 \mathrm{ml} \mathrm{HBSS} /$ CMF containing $0.125 \%$ trypsin. Retinae were washed twice with culture medium and mechanically dissociated by trituration through a flame-narrowed glass pipette in $1 \mathrm{ml}$ of culture medium. Average cell yield was $3.5-4 \times 10^{7}$ cells/retina.

For experimental cultures used for CAT determinations, 4-5 $\times 10^{5}$ cells in $800 \mu \mathrm{l}$ medium were seeded per well (16 mm diameter) in a multiwell plate (Falcon) that had been incubated overnight with $350 \mu \mathrm{l}$ poly-t.lysine $(0.1 \mathrm{mg} / \mathrm{ml})$ for coating. Culture medium was Dulbecco's modified Eagle's medium (DMEM) supplemented with $44 \mathrm{~mm} \mathrm{Na-}$ $\mathrm{HCO}_{3}, 2 \mathrm{~mm}$ glutamine, $100 \mathrm{U} / \mathrm{ml}$ penicillin, $100 \mathrm{U} / \mathrm{ml}$ streptomycin, and $5 \%$ heat-inactivated fetal calf serum (FCS). Factors, conditioned media (CMs), and extracts to be tested for CAT-stimulating activity were added $1 \mathrm{hr}$ after cell seeding. Control experiments ensured that corresponding volumes of media used for conditioning did not influence CAT activity by themselves. Cultures were grown for $7 \mathrm{~d}$ at $37^{\circ} \mathrm{C}$ in $5 \%$ $\mathrm{CO}_{2}-95 \%$ air, and $50 \%$ of the culture medium was replaced after $3 \mathrm{~d}$ by fresh medium containing the original concentration of additives.

For the preparation of retina-conditioned media (RCM), retinal cells were seeded at a density of $7500 \mathrm{cells} / \mathrm{mm}^{2}$ on Primaria (Falcon) culture dishes or flasks and grown in DMEM containing 10\% FCS. After the culture period indicated, medium was removed, cells were washed once with the medium to be conditioned, and $1 \mathrm{ml}$ medium was added per $2 \times 10^{6}$ cells originally seeded. DMEM supplemented with $10 \%$ FCS (DMEM/FCS), DMEM containing $\mathrm{N}_{2}$ supplements (DMEM/ $\mathrm{N}_{2}$ ), or
DMEM without supplements (DMEM/-) was used for conditioning as indicated. After $3 \mathrm{~d}$, the $\mathrm{CM}$ was removed, centrifuged for $10 \mathrm{~min}$ at $1000 \times g$ and stored frozen at $-30^{\circ} \mathrm{C}$.

Conditioned media and extracts. Dissociated cells from neonatal rat retina were obtained by a procedure virtually identical to that described for chicken retina. Cells were grown in DMEM containing $10 \%$ horse serum for 6-10 d and medium was conditioned as described above, using serum-free DMEM supplemented with the $\mathrm{N}_{2}$ components described by Bottenstein and Sato (1979). Growth conditions for $\mathrm{C}_{6}$ rat glioma cells (American Type Culture Collection) and preparation of $\mathrm{C}_{6}$ CM were described previously (Unsicker et al., 1984).

Choroid, iris, ciliary body and pigment epithelium (CIPE), retina, forebrain, tectum, and heart were dissected from 6-, 8-, or 15-d-old chick embryos for extraction. CIPE extract was prepared according to Barbin et al. (1984). The other tissues were homogenized with a glassglass homogenizer (Potter-Elvelijem) in 10 volumes (wt/vol) of ice-cold water and centrifuged at $100,000 \times g$ for $1 \mathrm{hr}$. The supernatants were filtered sterile and stored frozen at $-80^{\circ} \mathrm{C}$.

Biochemical determinations. Retinal cultures to be assayed for CAT activity were washed twice with PBS and incubated for $5 \mathrm{~min}$ at $37^{\circ} \mathrm{C}$ with $100 \mu \mathrm{l}$ of $10 \mathrm{~mm}$ sodium phosphate buffer, $\mathrm{pH} 7.4$, containing 10 mM EDTA and $0.5 \%$ Triton X-100. Aliquots were used for determination of CAT activity according to Fonnum (1975) and measurement of protein content according to Lowry et al. (1951). Specificity of CAT determinations was established by 2 methods. Enzyme activity was completely inhibited by an antiserum to chicken CAT (Johnson and Epstein, 1986) that was kindly supplied by Dr. Epstein, University of Wisconsin, and the radioactive product was completely degraded by added $\mathrm{AChE}$ when the assay was performed in the absence of esterase inhibitor.

Determination of cell survival. Retinal cultures were washed with PBS and incubated for $5 \mathrm{~min}$ with $100 \mu \mathrm{l} 0.25 \%$ trypsin, $0.1 \%$ EDTA in PBS, and $300 \mu \mathrm{l}$ DMEM with $10 \%$ FCS was added to each well. The cells were gently triturated to obtain a suspension of single cells, fixed by the addition of $100 \mu \mathrm{l}$ of $10 \%$ glutaraldehyde, and counted in a hemocytometer.

Immunocytochemistry. For immunocytochemical visualization of tetanus toxin binding, retinal cells were either grown on poly-L-lysinecoated coverslips or, for quantitative determinations, detached from the multiwell plate by trypsin treatment, as described above, triturated, and reseeded on coverslips at lower density. Cells were treated in sequence with tetanus toxin (diluted 1:50 in HBSS containing 0.2\% BSA), rabbit anti-tetanus toxin antiserum $(1: 300)$ and fluorescein isothiocynate (FITC)conjugated goat anti-rabbit IgG antiserum (Dynachtech; 1:50), and washed 3 times with HBSS/BSA after each step. Cells were fixed with $4 \%$ paraformaldehyde in $100 \mathrm{~mm}$ sodium phosphate buffer, $\mathrm{pH} 7.2$, and mounted in $10 \%$ glycerol.

Immunocytochemical staining for vimentin was performed on cultures fixed with methanol for $5 \mathrm{~min}$ at $-20^{\circ} \mathrm{C}$. Fixed cultures were incubated for $30 \mathrm{~min}$ each with rabbit anti-vimentin (Bioscience; diluted $1: 50$ in HBSS containing $1 \%$ BSA, $5 \%$ normal goat serum) and FITCconjugated goat anti-rabbit IgG antiscrum (1:50).

Immunostained cultures were examined with a Zeiss photomicroscope III equipped with phase-contrast and epifluorescence optics.

\section{Results}

\section{Stimulation of CAT activity}

During in avo development, C.AT activity in chicken neural retina becomes detectable between $\mathrm{E} 6$ and E8, and after E8 about a 10-fold increase of enzyme activity is observed within 5 d (unpublished observations; see also Crisanti-Combes et al., 1978). For this reason, cells dissociated from E8 chicken retina were used in this study. As shown in Figure 1, specific CAT activity in control cultures increases from $0.06 \mathrm{nmol} / \mathrm{min}$ per $\mathrm{mg}$ protein at $12 \mathrm{hr}$ after seeding to $0.47 \mathrm{nmol} / \mathrm{min}$ per $\mathrm{mg}$ protein at culture day 7. When grown in the presence of RCM, enzyme activity is further stimulated by about $100 \%$ after $7 \mathrm{~d}$ of incubation. In different experiments, RCM-induced CAT stimulation varied between 100 and $400 \%$. This variability could not be correlated with differences in the stimulating activity of RCMs, but more likely is caused by variations of the biological 

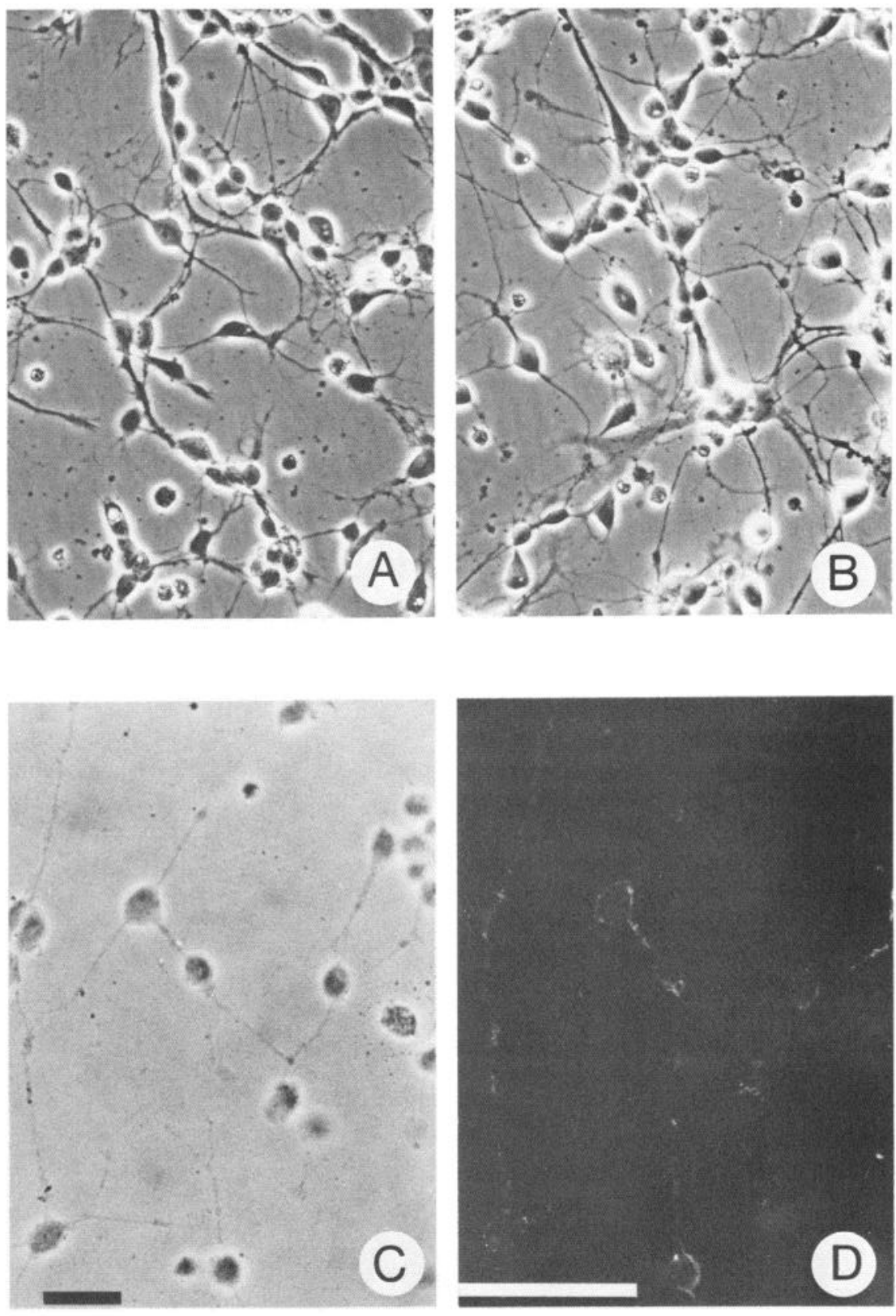

Figure 2. Cultures of dissociated cells from E8 chicken retina as used for the determination of CAT activity. Phasecontrast micrographs $(A, B)$ of living cells grown for $6 \mathrm{~d}$ in the absence $(A)$ or presence $(B)$ of RCM $(110 \mu \mathrm{l} / \mathrm{ml})$. $C$, $D$, Fixed cells after $7 \mathrm{~d}$ in culture, processed for tetanus toxin immunocytochemistry. The same field was photographed with phase-contrast optics $(C)$ and epifluorescence for FITC immunofluorescence $(D)$. Bar $(C) 50 \mu \mathrm{m}$, valid for all micrographs. material. NGF, which has been shown to promote cholinergic development in rat septal (Honegger and Lenoir, 1982; Hefti et al., 1985) and striatal (Martinez et al., 1985) cultures, has no effect on CAT activity in chicken retinal cultures, and neither spontaneous nor RCM-stimulated cholinergic development was inhibited by anti-NGF antibodies (Fig. 1).

Visual inspection under phase-contrast optics does not reveal any differences in the appearance of cultures grown in the presence or absence of RCM (Fig. 2, $A, B$ ). When cultured for $7 \mathrm{~d}$ on a highly adhesive substrate at moderate density, retinal cultures contain a low number of flat non-neuronal cells. The majority of the cells is of a neuronal phenotype with phase-bright appearance and neuritic processes of variable morphology, and can be shown to bind tetanus toxin (Fig. 2, Table 1). The cultures also contain a population of small, dark tetanus toxin-negative cells (Fig. 2, $C, D$ ), possibly representing immature photore- ceptors, as suggested by Beale et al. (1982). Occasionally such small cells contain oil droplets and exhibit a monopolar morphology (Fig. 2, $A, B$ ) resembling that of cultured chicken retinal cells, which were demonstrated as expressing conelike properties in vitro (Adler et al., 1984). Quantitative determination of protein content and cell number did not indicate that RCM might act via a general growth- or survival-supporting effect. Both parameters are not significantly changed when cultures are grown in the presence of RCM (Table 1). Moreover, RCM does not influence the percentage of tetanus toxin-binding cells. Evaluation of the percentage of non-neuronal vimentin-positive cells (see Fig. 3), the exact number of which is difficult to determine, did not indicate an increased proliferation of this cell type in the presence of RCM. Less than $10 \%$ of the cells were vimentinpositive both in control and in RCM-stimulated cultures. It is unlikely, therefore, that RCM stimulates the proliferation of 

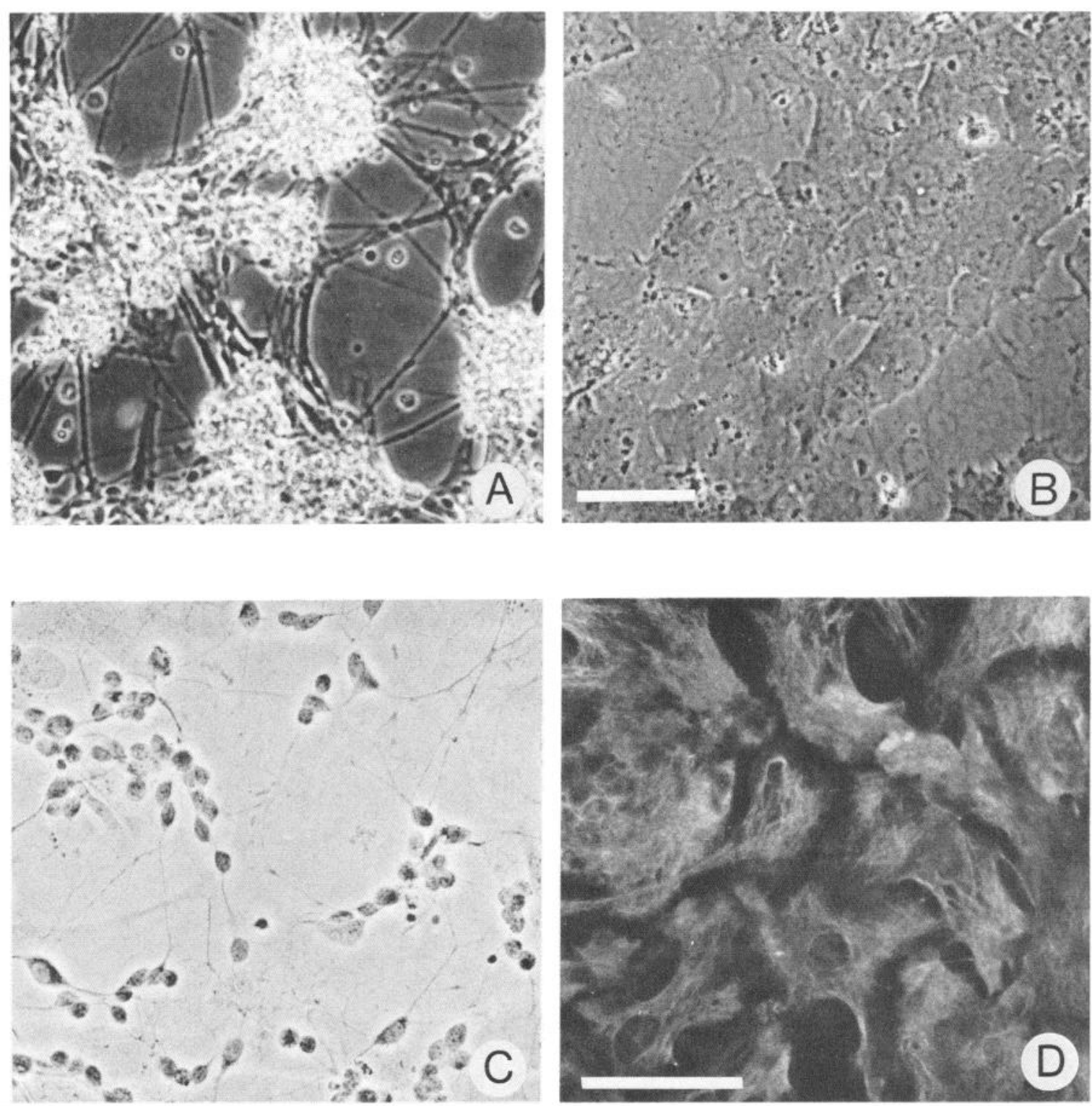

Figure 3. Cultures of dissociated cells from E8 chicken retina as used for conditioning of media. Compared to cultures shown in Figure 2, cells were grown at higher density $\left(7500 \mathrm{cell} / \mathrm{mm}^{2}\right)$ on a substrate of lower adhesiveness in DMEM containing higher serum concentrations (10\% FCS; see Materials and Methods). After $3 \mathrm{~d}(A)$ in culture, phase-bright neuronal cells have formed large aggregates interconnected by a network of fibers. Cultures grown for $27 \mathrm{~d}(B)$ consist almost entirely of flat non-neuronal cells. $C$ (phase-contrast) and $D$ (FITC fluorescence) show the same visual field of a "mixed" culture grown in DMEM/10\% FCS for $10 \mathrm{~d}$ after immunocytochemical staining for vimentin. Only flat cells that are hardly visible in phase-contrast after the staining procedure show vimentin immunoreactivity, which visualizes an intracellular network of vimentin filaments. Bars $(B, C), 50 \mu \mathrm{m}$.

non-neuronal cells, which, in turn, could promote differentiation of cholinergic neurons.

\section{Sources of CAT-stimulating activity}

Retinal cultures from 8-d-old embryonic chicken, as used for the preparation of conditioned media, are shown in Figure 3. Cells were seeded at higher density $\left(7500\right.$ cells $\left./ \mathrm{mm}^{2}\right)$ on a less adhesive substrate, and the culture medium contained higher concentrations of FCS (10\%) than did "neuronal" cultures used as an assay system for cholinergic development. Under these conditions, the neuronal cells form large aggregates that are connected by a network of fibers after $3 \mathrm{~d}$ in culture (Fig. $3 A$ ). The culture conditions favor the proliferation of non-neuronal cells, whereas neuronal cells die within 2-3 weeks. After 3 weeks, glial cells have grown to confluence and the cultures are virtually free of neurons (Fig. 3B). The flat cells represent a rather homogenous population of polygonal, phase-dark cells containing a filamentous network that can be visualized by immunostaining for the intermediate filament protein vimentin (Fig. 3, $C, D$ ). No vimentin-negative flat cells were detectable in confluent cultures, while spherical process-bearing neurons were consistently found to be negative. Tetanus toxin binding, used as marker for neuronal cells, was never observed on flat cells (not shown).

When media conditioned by "mixed" cultures (culture days 3-6) and by glial cultures (culture days 24-27) are compared, no difference is found between their capacities to support cholinergic development (Table 2), suggesting that mainly nonneuronal cells secrete the CAT-stimulating agent. Although se- 


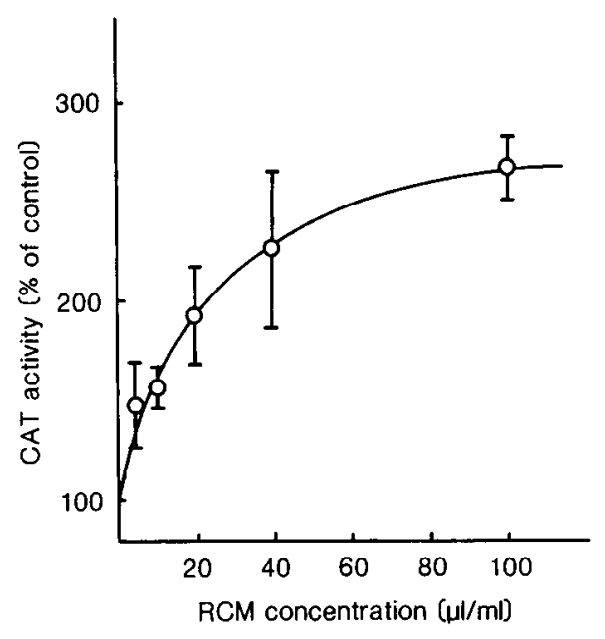

Figure 4. Dose dependence of RCM effects on CAT activity of neuronal retinal cultures. Cultures were grown in the presence of varying amounts of RCM, and enzyme activity was determined after $7 \mathrm{~d}$ in culture. RCM (DMEM without supplements) was conditioned by nonneuronal retinal cells after $27 \mathrm{~d}$ of incubation (see Fig. 3). Each value represents the mean of 3-4 determinations \pm SEM.

rum-containing medium had to be used to grow the cultures for longer periods, addition of serum or other supplements is not necessary during the period of conditioning (Table 2). This was tested because it has been reported that both hormones and growth factors present in sera may influence the conditioning process and the transmitter synthesis of neuronal cultures ( $\mathrm{Fu}-$ kada, 1980; Wolinsky and Patterson, 1985).

The effect of RCMs on CAT activity in the test cultures is dose-dependent and saturable (Figs. 4, 5). Titration of RCMs allows a quantitative comparison of RCMs produced by different cultures. Serum-free RCMs from glial cells containing about $200 \mu \mathrm{g}$ protein $/ \mathrm{ml}$ showed half maximal activity at $10-15 \mu \mathrm{l}$ added $/ \mathrm{ml}$ culture medium (Fig. 4). Thus, at 2-3 $\mu$ g protein $/ \mathrm{ml}$, enzyme activity is half maximally stimulated. Specific activities of RCMs from "mixed" cultures do not differ significantly when produced under standard conditions, i.e., between days 3 and 6 of incubation. Medium conditioned during the first 3 culture days, however, has about a 5-fold lower activity as calculated from the data of Figure 5. When retinal cultures prepared from 6-d-old embryos are used for conditioning, the resulting RCM contains very low activity that is not sufficient to maximally stimulate CAT even at the highest concentrations used. The data shown in Figure 5 seem to indicate that the production of the CAT-stimulating factor is age-dependent and is not significant before $\mathrm{E} 8$.

This conclusion is supported by the data of Table 3, which show that a CAT-stimulating factor is not only produced in

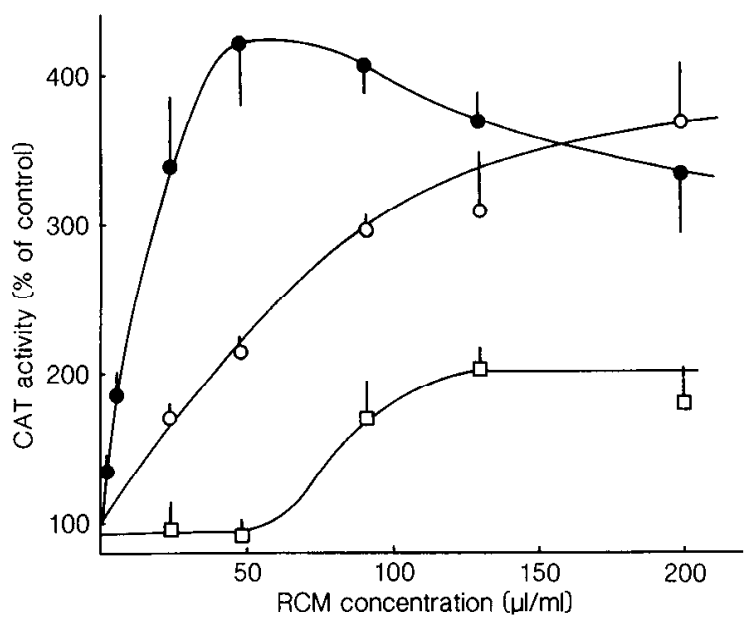

Figure 5. Comparison of CAT-stimulating activities of different RCMs. E6 (D) or E8 $(\mathbf{Q}, 0)$ retinal cultures were prepared and grown as described in Materials and Methods (see also Fig. 3). DMEM/ $\mathrm{N}_{2}$ was conditioned between 0 and $3 \mathrm{~d}(0)$ or 3 and $6 \mathrm{~d}(\Theta, \square)$ of incubation. The CATstimulating activity of the different RCMs was then titrated as described in the legend to Figure 4. Each value represents the mean of 3 determinations \pm SEM.

culture, but is also present in vivo, and that at E6 chicken retinae obviously contain significantly lower concentrations of the factor than $2 \mathrm{~d}$ later in development. No difference was found between E8 and E15. Table 3 also shows that the production of such a factor is rather specific for retinal tissue. In particular, extracts from optic lobe or whole brain of chicken embryos had no effect on CAT activity. Embryonic chicken heart extract (Nishi and Berg, 1979; Varon and Adler, 1980), pig brain extract (Barde et al., 1982; Lindsay et al., 1985), and $\mathrm{C}_{6}$ glioma-CM (Edgar et al., 1979, 1981; Unsicker et al., 1984), all of which have been reported to possess NTF activity, with different specificites for peripheral neurons or other neural crest derivatives, are inactive in the test system used here. Measurements of brain and heart extract activities are, however, of limited sensitivity because these additives seem to have toxic effects on retinal cultures at concentrations that are optimal for retinal extracts (Table 3). Of particular interest is the finding that extracts prepared from an eye tissue component containing ciliary body, iris and pigment epithelium (CIPE), but free of neural retina, stimulates CAT activity to the same extent as RCM. CIPE has been used as a source for the isolation of a ciliary neuronotrophic factor (CNTF) with survival-supporting activity for cholinergic parasympathic neurons (Barbin et al., 1984).

\section{Characterization of CAT-stimulating activity}

In all experiments performed to obtain basic information about its molecular nature, the CAT-stimulating factor present in RCM

Table 1. Effect of retina-conditioned medium on CAT activity, protein content, cell survival, and percentage of tetanus toxin-positive cells in retinal cultures

\begin{tabular}{lclll} 
& $\begin{array}{l}\text { CAT activity } \\
(\mathrm{pmol} / \mathrm{min} / \text { well })\end{array}$ & $\begin{array}{l}\text { Protein } \\
(\mu \mathrm{g} / \text { well })\end{array}$ & $\begin{array}{l}\text { Surviving } \\
\text { cells/wells } \\
\left(\times 10^{-3}\right)\end{array}$ & $\begin{array}{l}\text { Tetanus toxin- } \\
\text { positive cells } \\
(\%)\end{array}$ \\
\hline Control & $6.1 \pm 1.0$ & $11.1 \pm 1.4$ & $258 \pm 22$ & $74.0 \pm 2$ \\
RCM $(110 \mu \mathrm{l} / \mathrm{ml})$ & $11.8 \pm 1.2$ & $13.3 \pm 0.6$ & $258 \pm 34$ & $78.5 \pm 1$ \\
\hline
\end{tabular}

Values represent the mean of at least 3 measurements \pm SEM. 


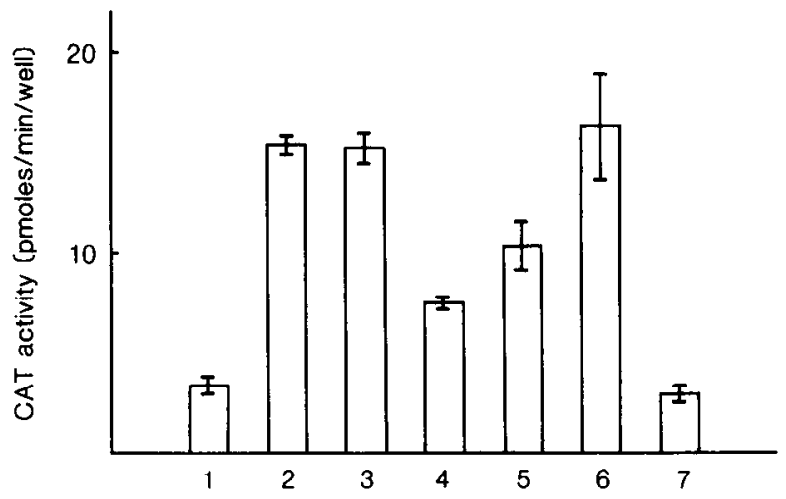

Figure 6. Effect of various treatments on CAT-stimulating activity of RCM. Neuronal retinal cultures were grown in the absence $(l)$ or presence $(2-7)$ of $\mathrm{RCM}(110 \mu \mathrm{l} / \mathrm{ml})$ that had been treated as follows: no treatment (2); dialyzed for $24 \mathrm{hr}$ against phosphate-buffered saline (3); precipitated with ammonium sulfate ( $45 \%$ saturation), pellet redissolved in water to the original volume, and dialyzed (4); as in 4 but $65 \%$ saturated ammonium sulfate was used (5); incubated at $60^{\circ} \mathrm{C}$ for $20 \mathrm{~min}$ (6); incubated at $100^{\circ} \mathrm{C}$ for $10 \mathrm{~min}(7)$. Each value represents the mean of 4 determinations \pm SEM.

behaved like a protein (Fig. 6). It can be concentrated by ultrafiltration and is nondialyzable, indicating a molecular weight of more than $15 \mathrm{kDa}$. After ultrafiltration or dialysis, the activity is quantitatively retained, as determined by titrating the resulting RCM fractions (data not shown). The active molecule is precipitable with ammonium sulfate at $45-60 \%$ saturation. RCM activity is sensitive to treatment with proteases like trypsin and papain but is resistant to other hydrolytic enzymes like neuraminidase and DNAase 1. The putative polypeptide factor is, however, unusually stable with heat treatment. Its activity is not altered after $20 \mathrm{~min}$ at $60^{\circ} \mathrm{C}$ and only partially destroyed after $20 \mathrm{~min}$ at $90^{\circ} \mathrm{C}$ (not shown).

\section{Discussion}

In this study neuronal monolayer cultures prepared from embryonic chicken retina were used as a model system to investigate the existence of extrinsic factors influencing the development of CNS neurons. The role of NTF in the development of PNS neurons is well documented because a number of rel-

Table 2. Influence of the conditioning protocol on CAT-stimulating activity of conditioned media

\begin{tabular}{lll} 
& \multicolumn{2}{c}{ CAT activity } \\
\cline { 2 - 3 } & pmol/min/well & $\begin{array}{l}\text { \% of } \\
\text { Control }\end{array}$ \\
\hline $\begin{array}{l}\text { Control (without RCM) } \\
\text { RCM conditioned by } \\
\text { mixed cultures in } \\
\text { DMEM/10\% FCS }\end{array}$ & $4.01 \pm 0.75$ & 100 \\
DMEM/N & & \\
DMEM/- & $8.73 \pm 0.28$ & 218 \\
glial cultures in & $6.54 \pm 0.66$ & 163 \\
DMEM/- & $8.75 \pm 1.9$ & 218 \\
& & \\
\end{tabular}

DMEM with or without supplements was conditioned either by mixed cultures (Fig. $3 A$ ) at days $3-6$ in cultures or by glial cultures (Fig. $3 B$ ) at days $27-30$. RCMs $(110 \mu \mathrm{l} / \mathrm{ml})$ were added to neuronal test cultures and CAT activity in these cultures was determined after $7 \mathrm{~d}$ of incubation. Values represent the mean of 4 measurements \pm SEM
Table 3. CAT-stimulating activity in extracts and conditioned media

\begin{tabular}{lcc} 
& Concentrations & $\begin{array}{l}\text { CAT } \\
\text { activity (\% } \\
\text { of controls) }\end{array}$ \\
\hline Chicken retina-CM & $110 \mu \mathrm{l} / \mathrm{ml}$ & $218 \pm 15$ \\
Rat retina-CM & $110 \mu \mathrm{l} / \mathrm{ml}$ & $190 \pm 9$ \\
Chicken retina extract (E6) & $20 \mu \mathrm{g}$ protein $/ \mathrm{ml}$ & $157 \pm 18$ \\
Chicken retina extract (E8) & $20 \mu \mathrm{g}$ protein $/ \mathrm{ml}$ & $227 \pm 36$ \\
Chicken retina extract (E15) & $20 \mu \mathrm{g}$ protein $/ \mathrm{ml}$ & $239 \pm 4$ \\
Chicken tectum extract (E15) & $100 \mu \mathrm{g}$ protein $/ \mathrm{ml}$ & $104 \pm 9$ \\
Chicken brain extract (E15) & $100 \mu \mathrm{g}$ protein $/ \mathrm{ml}$ & $110 \pm 11$ \\
Chicken heart extract (E15) & $100 \mu \mathrm{g}$ protein $/ \mathrm{ml}$ & $64 \pm 10$ \\
CIPE & $20 \mu \mathrm{g}$ protein $/ \mathrm{ml}$ & $244 \pm 11$ \\
Pig brain extract & $150 \mu \mathrm{g}$ protein $/ \mathrm{ml}$ & $96 \pm 20$ \\
$\mathrm{C}_{6}$ glioma-CM & $110 \mu \mathrm{l} / \mathrm{ml}$ & $104 \pm 5$ \\
\hline
\end{tabular}

Neuronal retinal cultures were grown for $7 \mathrm{~d}$ in the presence of the indicated concentrations of additives. CAT activity is given as percentage of controls grown without additives. Each value represents the mean of 4 measurements \pm SEM.

atively homogenous neuronal culture systems are easily available. In the case of the CNS, however, the establishment of an appropriate assay system for NTF activity is crucial. The cholinergic retinal system was chosen as a model because AChsynthesizing cells are well characterized in vivo and, following the theory that NTFs are produced by either the target cells or the glial environment of responsive neurons, the retina itself was expected to be the source of a putative cholinergic factor.

Two types of retinal cultures were used throughout this study. Dissociated neural retina cells seeded at moderate density on a highly adhesive substratum served as the assay system for in vitro development of CAT activity. Under these conditions, cultures are virtually free of flat non-neuronal cells even after $7 \mathrm{~d}$, as is described in detail by Adler et al. (1982). The second culture type was designed to get optimum conditioning of media that were tested for CAT-stimulating activity. By growing the cells at high density $\left(7.5 \times 10^{3} \mathrm{cells} / \mathrm{mm}^{2}\right)$ on a less adhesive substratum, it was possible to establish pure non-neuronal cell cultures. Although it is difficult to demonstrate to what extent a cell population in culture corresponds to a cell type found in vivo, there is convincing evidence that the flat cell population in chicken retinal cultures is derived from immature Müller cells. Contamination by nonretinal cells can be excluded in cultures carefully prepared from the nonvascularized chicken retina. The morphological appearance of the flat cells, the absence of neuronal markers like tetanus toxin binding (data not shown; Adler et al., 1982; Beale et al., 1982), and a number of immunocytochemical and biochemical glial cell characteristics found in these cells (Bartlett et al., 1981; Moscona and Linser, 1983; Li and Sheffield, 1984; Sarthy et al., 1985) clearly indicate their glial origin. In contrast to mammalian retinae, Müllerian glia are the only glial cell type found in chicken retina. As shown in Figure 3, all the flat cells in culture express vimentin (see also Iemmon and Rieser, 1983), which is the specific intermediate filament protein of both immature and differentiated Müller cells (Lemmon and Rieser, 1983; Dräger et al., 1984; $\mathrm{Li}$ and Sheffield, 1984). The non-neuronal flat cells in chicken retinal cultures can also be hormonally induced to express glutamine synthetase, an enzyme that is specifically localized in Müller cells of the chicken retina (Moscona and Linser, 1983). 
CAT activity in chicken retinal cultures was found to increase from about $50 \mathrm{pmol} / \mathrm{min}$ per $\mathrm{mg}$ protein shortly after seeding to about $500 \mathrm{pmol} / \mathrm{min}$ per $\mathrm{mg}$ protein after $7 \mathrm{~d}$ of incubation. This is in agreement with the results reported by Crisanti-Combes et al. (1978), who also showed that in vivo CAT becomes detectable between E6 and E8 and increases 5-10 times within a few days. As already mentioned, enzyme activity determined after $7 \mathrm{~d}$ in culture varied considerably in different experiments. This could be due to the fact that cultures were prepared at a critical phase of cholinergic retinal development. Inclusion of RCM, however, always resulted in at least a 2 -fold stimulation of CAT activity. Added RCM in neural test cultures diminished CAT stimulation when cultures were grown at increasing densities (data not shown), reflecting a self-conditioning process in these cultures. This finding lends further support to the conclusion that cholinergic development is dependent on soluble factors produced by other retinal cell types. RCM-mediated increase of CAT is not caused by a general survival-supporting effect, as indicated by the unaltered protein content, cell number, and percentage of tetanus toxin-positive cells in stimulated, as compared to control, cultures (Table 1). It is also unlikely that RCM acts by stimulating the proliferation of non-neuronal cells that in turn could exert an increased supportive effect on neurons, as the proportion of flat cells is not changed in the presence of RCM. Whether stimulation of CAT activity by RCM is due to enzyme induction, to stimulating effects on the survival of cholinergic neurons, or to enhanced proliferation of precursor cells cannot be determined from the present data. Evidence for one of these possibilities might be obtained from quantitative determination of the number of cholinergic neurons surviving in the presence or absence of RCM. However, attempts to identify CAT-expressing neurons by immunocytochemical methods have not been successful to date.

Besides polypeptide factors, low-molecular-weight agents have been reported to be responsible for neuronotrophic activities on CNS neurons observed in conditioned media (Müller et al., 1984; Selak et al., 1985). RCM activity for cholinergic retinal neurons was shown to be associated with a macromolecular component that, from its sensitivity to proteases and its stability with other hydrolytic enzymes, was characterized as a polypeptide (Fig. 6). This is taken to be evidence that a polypeptide factor is responsible for the effects of RCM on CAT activity, although the participation of more than one protein cannot be excluded. Enzyme stimulation by RCM is dose-dependent and saturable, and half-maximal activity is obtained at a protein concentration of $2-3 \mu \mathrm{g} / \mathrm{ml}$, corresponding to a 100 -fold dilution of the CM. The specific activity of RCM is higher compared to other CMs that contain trophic activities of varying target-cell specificities (Barde et al., 1983; Müller et al., 1984; Unsicker et al., 1984; Varon and Manthorpe, 1984).

Important to the concept of neuronotrophic interaction between non-neuronal and neuronal cells (Varon and Adler, 1981; Perez-Polo, 1985) is the issue of whether neuronal populations specifically respond to trophic substances produced either by their target tissue or by their glial environment. Convincing evidence supporting this concept has been supplied with respect to peripheral neurons. For instance, NGF concentrations in target organs have been shown to correlate with sympathetic innervations (Korsching and Thoenen, 1983), and ciliary neuronotrophic factor has been purified from target tissue (Barbin et al., 1984) and peripheral nerve tissue (Manthorpe et al., 1985). In brain, neuronotrophic interactions are much more difficult to elucidate, for two main reasons. First, in most cases, appropriate neuronal culture systems containing identifiable neuronal populations with which to measure specific NTF activities have not been established. Second, corresponding NTFproducing tissue or cells cannot usually be isolated. Therefore, as far as CNS is concerned, it is of particular interest that the protein factor described here seems to be specifically produced by retinal cells and that, at least in vitro, Müllerian glia-derived cells could be identified as the activity-secreting cell type. Development of cultured cholinergic retinal neurons was supported by CMs from chicken and rat retinal cells and by retinal extracts (Table 3). However, chicken tectum or whole brain extracts, pig brain extract, and $\mathrm{C}_{6}$ glioma-CM did not contain detectable amounts of activity in this assay system (Table 3 ). Media conditioned by rat or chicken brain cultures were also ineffective (data not shown). All the extracts and conditioned media found to be inactive in this study have been described as exhibiting trophic or differentiation-supporting activities for neurons of different origin (Varon and Adler, 1981; Barde et al., 1983; Berg, 1984; Varon and Manthorpe, 1984; Hatanaka and Tsukin, 1986; Kessler et al., 1986). In particular, chicken tectum (Nurcombe and Bennett, 1981) and pig brain (Turner, 1985; Johnson et al., 1986) produce NTFs that enhance survival of retinal ganglion cells in vitro. From the data presented in Table 3 it is concluded, therefore, that RCM activity for cholinergic retinal neurons is not identical to any of the activities mentioned above. Interestingly, however, CIPE extract, which contains high concentrations of CNTF, is as potent as RCM. CNTF has been purified on the basis of its neuronotrophic effects on cholinergic parasympathetic neurons, and only peripheral neurons have been rcported to respond to it (Barbin et al., 1984). Besides CNTF, 2 other "peripheral" NTFs have been purified so far and both, NGF (Honegger and Lenoir, 1982; Hefti et al., 1985; Hefti, 1986) and brain-derived neuronotrophic factor (BDNF; Johnson et al., 1986), have recently been shown to address specific neuronal populations in the basal forebrain and the retina, respectively. It is tempting, therefore, to interpret the results of this study as indicating that cholinergic retinal neurons may represent a CNS target for CNTF or a CNTF-like factor.

A "cholinergic" polypeptide factor has been purified from medium conditioned by cultured rat heart cells (Fukada, 1985); in vitro it is able to induce cholinergic development of sympathetic neurons, normally expressing a noradrenergic phenotype, without affecting the survival and growth of these cells (Patterson and Chun, 1977; Patterson, 1978). The same, or a very similar, factor partially purified from rat skeletal muscle-CM has been shown to support the development of cholinergic spinal cord neurons (Giess and Weber, 1984). The data presented here do not exclude the possibility that such a "specifying" factor (Varon and Adler, 1981) is present in RCM, and induces CAT activity in retinal neurons normally destined to express a noncholinergic transmitter phenotype. Heart extracts and $\mathrm{C}_{6} \mathrm{CM}$, however, which have been suggested as containing the "cholinergic" factor influencing ACh metabolism in rat spinal cord cultures did not stimulate CAT activity of retinal neurons (Table 3).

Another finding of this study that fits the NTF concept was the observation that CAT-stimulating activity is low in RCM and retinal extracts at E6 and increases beyond E8 (Fig. 5, Table 3). Thus the period of rapid cholinergic development in vivo (Crisanti-Combes et al., 1978) correlates with the time of enhanced production of a cholinergic factor within the retina. 


\section{References}

Adler, R., P. J. Magistretti, A. G. Hyndman, and W. J. Shoemaker (1982) Purification and cytochemical identification of neuronal and non-neuronal cells in chick embryo retina cultures. Dev. Neurosci. 5: 27-39.

Adler, R., J. D. Lindsey, and C. L. Elsner (1984) Expression of conelike properties by chick embryo neural retina cells in glia-free monolayer cultures. J. Cell Biol. 99: 1173-1178.

Barbin, G., M. Manthorpe, and S. Varon (1984) Purification of the chick eye ciliary neuronotrophic factor. J. Neurochem. 43: 14681478.

Barde, Y.-A., D. Edgar, and H. Thoenen (1982) Purification of a new neuronotrophic factor from mammalian brain. EMBO J. 5: 549-553.

Barde, Y.-A., D. Edgar, and H. Thoenen (1983) New neuronotrophic factors. Annu. Rev. Physiol. 45: 601-612.

Bartlett, P. F., M. D. Noble, R. M. Pruss, M. C. Raff, S. Rattray, and C. A. Williams (1981) Rat neural antigen-2 (Ran-2): A cell surface antigen on astrocytes, ependymal cells, Müller cells and leptomeninges defined by a monoclonal antibody. Brain Res. 204: 339-354.

Baughman, R. W., and C. R. Bader (1977) Biochemical characterization and cellular localization of the cholinergic system in the chicken retina. Brain Res. 138: 469-485.

Beale, R., D. Nicholas, V. Neuhoff, and N. N. Osborne (1982) The binding of tetanus toxin to retinal cells. Brain Res. 248: 141-149.

Berg, D. K. (1984) New neuronal growth factors. Annu. Rev. Neurosci. 7: $149-170$.

Bottenstein, J. E., and G. H. Sato (1979) Growth of a rat neuroblastoma cell line in serum-free supplemented medium. Proc. Natl. Acad. Sci. USA 76: 514-517.

Crisanti-Combes, P., B. Dessac, and G. Calothy (1978) Choline acetyl transferase activity in chick embryo neuroretinas during development in ovo and in monolayer cultures. Dev. Biol. 65: 228-232.

Dräger, U. C., D. L. Edwards, and C. J. Barnstable (1984) Antibodies against filamentous components in discrete cell types of the mouse retina. J. Neurosci. 4: 2025-2042.

Edgar, D., Y.-A. Barde, and H. Thoenen (1979) Induction of fibre outgrowth and choline acetyltransferase in PC12 pheochromocytoma cells by conditioned media from glial cells and organ extracts. Exp. Cell. Res. 121: 353-361.

Edgar, D., Y.-A. Barde, and H. Thoenen (1981) Subpopulations of chick sympathetic neurons differ in their requirements for survival factors. Nature 289: 294-295.

Fonnum, F. (1975) A radiochemical method for the determination of choline acetyltransferase. J. Neurochem. 24: 407-409.

Fukada, K. (1980) Hormonal control of neurotransmitter choice in sympathetic neurone cultures. Nature 287: 553-555.

Fukada, K. (1985) Purification and partial characterization of a cholinergic neuronal differentiation factor. Proc. Natl. Acad. Sci. USA 82: 8795-8799.

Giess, M.-C., and M. Weber (1984) Acetylcholine metabolism in rat spinal cord cultures: Regulation by a factor involved in the determination of the neurotransmitter phenotype of sympathetic neurons. J. Neurosci. 4: 1442-1452.

Hamburger, V., and H. L. Hamilton (1951) A series of normal stages in the development of the chick embryo. J. Morphol. 84: 49-92.

Hatanaka, K., and H. Tsukui (1986) Differential effects of nerve growth factor and glioma-conditioned medium on neurons cultured from various regions of fetal rat central nervous system. Dev. Brain Res. 30: 47-56.

Hefti, F. (1986) Nerve growth factor promotes survival of septal cholinergic neurons after fimbrial transsections. J. Neurosci. 6: 21552162.

Hefti, F., J. Hartikka, F. Eckenstein, H. Grahn, R. Heumann, and M Schwab (1985) Nerve growth factor increases choline acetyltransferase but not survival or fiber outgrowth of cultured fetal septal cholinergic neurons. Neuroscience 1: 55-68.

Hefti, F., J. Hartikka, A. Salvatierra, W. J. Weiner, and D. C. Mash (1986) Localization of nerve growth factor receptors in cholinergic neurons of the human basal forebrain. Neurosci. Lett. 69: 37-41.

Hofmann, H.-D., and K. Unsicker (1982) The seminal vesicle of the bull: A new and very rich source of nerve growth factor. Eur. J. Biochem. 128: 421-426.
Honegger, P., and D. Lenoir (1982) Nerve growth factor (NGF) stimulation of cholinergic telencephalic neurons in aggregating cell cultures. Dev. Brain Res. 3: 229-238.

Iuvone, P. M. (1986) Neurotransmitters and neuromodulators in the retina: Regulation, interactions and cellular effects. In The Retina, pt. 2, R. Adler and D. Faber, eds., pp. 1-72, Academic, Orlando, FL.

Johnson, C. D., and M. L. Epstein (1986) Monoclonal antibodies and polyvalent antiserum to chicken choline acetyltransferase. J. Neurochem. 46: 968-976.

Johnson, J. E., Y.-A. Barde, M. Schwab, and H. Thoenen (1986) Brainderived neuronotrophic factor supports survival of cultured rat retinal ganglion cells. J. Neurosci. 6: 3031-3038.

Kaneko, A. (1979) Physiology of the retina. Annu. Rev. Neuroci. 2: 169-191.

Kessler, J. A., G. Conn, and V. B. Hatcher (1986) Isolated plasma membranes regulate neurotransmitter expression and facilitate effects of a soluble brain cholinergic factor. Proc. Natl. Acad. Sci. USA 83 . $3528-3532$.

Korsching, S., and H. Thoenen (1983) Levels of nerve growth factor in sympathetic ganglia and corresponding target organs of the rat: Correlation with the density of sympathetic innervation. Proc. Natl. Acad. Sci. USA 80: 3513-3516.

Large, T. H., S. C. Bodary, D. O. Clegg, G. Weskamp, U. Otten, and L. F. Reichardt (1986) Nerve growth factor gene expression in the developing rat brain. Science 234: 352-355.

Lemmon, V., and G. Rieser (1983) The developmental distribution of vimentin in the chicken retina. Dev. Brain Res. 11: 191-197.

Levi-Montalcini, R., and P. U. Angeletti (1968) Nerve growth factor. Physiol. Rev. 48: 534-569.

Li, H.-P., and J. B. Sheffield (1984) Isolation and characterization of flat cells, a subpopulation of the embryonic chick retina. Tissue Cell 16: 843-857.

Lindsay, R. M., H. Thoenen, and Y.-A. Barde (1985) Placode and neural crest-derived sensory neurons are responsive at early developmental stages to brain-derived neurotrophic factor. Dev. Biol. 112. 319-328.

Lowry, O. H., N. J. Rosenbrough, A. L. Farr, and R. J. Randall (1951) Protein measurement with the Folin phenol reagent. J. Biol. Chem. 193: 265-275

Manthorpe, M., S. D. Skaper, L. R. Williams, and S. Varon (1985) Purification of adult sciatic nerve ciliary neuronotrophic factor. Brain Res. 367: 282-286.

Martinez, H. J., C. F. Dreyfus, G. Miller Jonakait, and I. B. Black (1985) Nerve growth factor promotes cholinergic development in brain striatal cultures. Proc. Natl. Acad. Sci. USA 82:7777-7781.

Masland, R. H., J. W. Mills, and S. A. Hayden (1984) Acetylcholinesynthesizing amacrine cells: Identification and selective staining by using autoradiography and fluorescent markers. Proc. R. Soc. Lond. [Biol.] 223: 79-100.

McCaffery, C. A. , M. R. Bennett, and B. Dreher (1982) The survival of neonatal rat retinal ganglion cells in vitro is enhanced in the presence of appropriate parts of the brain. Exp. Brain Res. 48: 377-386.

Millar, T., K. Ishimoto, C. D. Johnson, M. L. Epstein, I. W. Chubb, and I. G. Morgan (1985) Cholinergic and acetylcholinesterase-containing neurons of the chicken retina. Neurosci. Lett. 61:311-316.

Moscona, A. A., and P. Linser (1983) Developmental and experimental changes in retinal glia cells: Cell interactions and control of phenotype expression and stability. Curr. Top. Dev. Biol. 18: 155188

Müller, H. W., S. Beckh, and W. Seifert (1984) Neurotrophic factor for central neurons. Proc. Natl. Acad. Sci. USA 81: 1248-1252.

Neal, M. J. (1983) Cholinergic mechanisms in the vertebrate retina. Prog. Ret. Res. 2: 191-212.

Nishi, R., and D. K. Berg (1979) Survival and development of ciliary ganglion neurones grown alone in culture. Nature 277: 232-234.

Nurcombe, V., and M. R. Bennett (1981) Embryonic chick retinal ganglion cells identified in vitro: Their survival is dependent on a factor from the optic tectum. Exp. Brain Res. 44: 249-258.

Patterson, P. H. (1978) Environmental determination of autonomic ncurotransmittcr functions. Annu. Rcv. Ncurosci. 1: 1-17.

Patterson, P. H., and L. L. Y. Chun (1977) The induction of acetylcholine synthesis in primary cultures of rat sympathetic neurons. I. Effects of conditioned medium. Dev. Biol. 56: 263-280. 
Perez-Polo, J. R. (1985) Neuronotrophic factors. In Cell Culture in the Neurosciences, J. E. Bottenstein and G. Sato, eds., pp. 95-123, Plenum, New York.

Ramon y Cajal, S. (1895) The Structure of the Retina (trans. 1972), Thomas, Springfield, IL.

Sarthy, P. J. (1985) Establishment of Müller cell cultures from adult rat retina. Brain Res. 337: 138-141.

Schmidt, M., H. Wässle, and M. Humphrey (1985) Number and distribution of putative cholinergic neurons in the cat retina. Neurosci. Lett. 59: 235-240.

Selak, I., S. D. Skaper, and S. Varon (1985) Pyruvate participation in the low molecular weight trophic activity for CNS neurons in glia conditioned media. J. Neurosci. 5: 23-28.

Sterling, P. (1983) Microcircuitry of the cat retina. Annu. Rev. Neurosci. 6: 149-185.

Tanaka, H., and H. Tsukui (1986) Differential effects of nerve-growth factor and glioma-conditioned medium on neurons cultured from various regions of fetal rat central nervous system. Dev. Brain Res. $30: 47-56$.

Thoenen, H., and Y.-A. Barde (1980) Physiology of nerve growth factor. Physiol. Rev. 60: 1284-1335.

Turner, J. E. (1985) Promotion of neurite outgrowth and cell survival in dissociated fetal rat retinal cultures by a fraction derived from a brain extract. Dev. Brain Res. 18: 265-274.

Unsicker, K., J. Vey, H.-D. Hofmann, T. H. Müller, and A. J. Wilson (1984) C6 glioma cell conditioned medium induces neurite outgrowth and survival of rat chromaffin cells in vitro: Comparison with the effects of nerve growth factor. Proc. Natl. Acad. Sci. USA 81: 2242-2246.

Varon, S., and R. Adler (1980) Nerve growth factors and control of nerve growth. In Current Topics in Developmental Biology, vol. 16, pt. 2, R. K. Hunt, ed., pp. 207-252, Academic, New York.

Varon, S., and R. Adler (1981) Trophic and specifying factors directed to neuronal cells. Adv. Cell Neurobiol. 2: 115-163.

Varon, S., and M. Manthorpe (1984) Trophic and neurite-promoting factors for cholinergic neurons. In Cellular and Molecular Biology of Neuronal Development, J. B. Black, ed., pp. 251-275, Plenum, New York.

Voigt, T. (1986) Cholinergic amacrine cells in the rat retina. J. Comp. Neurol. 248: 19-35.

Wolinsky, E. J., and P. H. Patterson (1985) Rat serum contains a developmentally regulated cholinergic inducing activity. J. Neurosci. 5: 1509-1512. 